\title{
Floral Organogenesis in Five Genera of the Marantaceae and in Canna (Cannaceae)
}

\author{
Bruce K. Kirchoff \\ American Journal of Botany, Volume 70, Issue 4 (Apr., 1983), 508-523.
}

Kirchoff, B. K.1983. Floral organogenesis in five genera of the Marantaceae and in Canna (Cannaceae). American Journal of Botany 70: 508-523.

Made available courtesy of the Botanical Society of America:

http://www.jstor.org/stable/i341826

Your use of the JSTOR archive indicates your acceptance of JSTOR' s Terms and Conditions of Use, available at http://www.jstor.org/about/terms.html. JSTOR' s Terms and Conditions of Use provides, in part, that unless you have obtained prior permission, you may not download an entire issue of a journal or multiple copies of articles, and you may use content in the JSToR archive only for your personal, non-commercial use.

Each copy of any part of a JSTOR transmission must contain the same copyright notice that appears on the screen or printed page of such transmission.

American Journal of Botany is published by Botanical Society of America. Please contact the publisher for further permissions regarding the use of this work. Publisher contact information may be obtained at http://www.jstor.org/journals/botsam.html.

American Journal of Botany

C191983 Botanical Society of America

JSTOR and the JSTOR logo are trademarks of JSTOR, and are Registered in the U.S. Patent and Trademark Office. For more information on JSTOR contact jstor-info@ umich.edu.

(C)2001 JSTOR

http://www.jstor.org/ 


\title{
FLORAL ORGANOGENESIS IN FIVE GENERA OF THE MARANTACEAE AND IN CANNA (CANNACEAE) ${ }^{1}$
}

\author{
BRUCE K. KIRCHOFF 2 \\ Department of Botany, Louisiana State University, Baton Rouge, Louisiana 70803
}

\author{
ABS TR ACT
}

\begin{abstract}
The paired flowers of all species of the Marantaceae studied, except Monotagma plurispicatum, are produced through the division of an apical meristem with a tunica-corpus structure. The solitary flowers of $M$. plurispicatum develop from a similar meristem which does not bifurcate. The paired flowers of Canna indica are produced in the axil of a florescence bract through the formation of a bract and an axillary flower on the side of the primordium which gives rise to the largest flower of the pair. The sequence of organ initiation for both families is: calyx, corolla and inner androecial whorl, outer androecial whorl, gynoecium. The sequence of sepal formation is opposite in the two families. In the Cannaceae it leads directly into the spiral ereated by the formation of the other organs, while in the Marantaceae the sequence of sepal formation follows a spiral opposite to that of the other floral organs. The members of the corolla and inner androecial whorl separate from common primordia. In general these common primordia separate into a petal and an inner androecial member through the initiation of two growth centers, at the same level, in the dorsal and ventral flanks of the primordium. In Ischnosiphon elegans and Pleiostachya pruinosa the stamen is initiated at a lower position than the petal in the ventral flank of the common primordium. A similar pattern of initiation is described for the callose staminode in Marantochloa purpurea and Canna indica. This pattern is interpreted as a variation on the more generalized pattern of inner androecial formation found in the other genera.
\end{abstract}

FLoRAL oRGANoGENESIS and floral growth in five genera of the Marantaceae, and one species of Canna (Cannaceae) will be explored in a series of two papers of which this is the first. The species under study include: Calathea leopardinia, Calathea lancifolia, Calathea vinosa, Ischnosiphon elegans, Marantochloa purpurea, Monotagma plurispicatum, Pleiostachya pruinosa (all Marantaceae), and Canna indica (Cannaceae). This paper presents a description and comparison of the patterns of organogenesis found in these species.

The Marantaceae and Cannaceae are well circumscribed pan-tropical groups of plants some of whose members are of economic importance (Maranta arundinacea - arrowroot

Received for publication 11 February 1982; revision accepted 2 August 1982.

This paper is based on a portion of a dissertation submitted in partial fulfillment of the requirements for the degree of Doctor of Philosophy in the Department of Botany in the Graduate School of Duke University. I am deeply indebted to Dr. R. A. White for his advice and guidance during the completion of my degree. I am also grateful to Mr. Russell Goddard for his help in the preparation of this manuscript, Sally Baker for preparing Fig. 1, 3 and 4, and to Dr. Shirley Tucker, Dr. U. Posluszny, and an unidentified reviewer for their suggestions to improve the manuscript. The SEM work included in this paper was supported by a Duke University Graduate School Research Award.

Present address: Dept. Botany, Hebrew University of Jerusalem, 91904 Jerusalem, Israel. flower; Maranta spp., Calathea spp. - house plants). Genera of these families were selected for study for several reasons: 1) floral development was not well known; 2) Andersson's (1977) revision of the genus Ischnosiphon includes an assessment of the relationships of the neo-tropical genera which allowed the selection of a natural subset of the family for study; and 3) the position of the Marantaceae in the order Zingiberales allowed the identification of the Cannaceae as its sister group (that group which shares a common ancestor with the Marantaceae and with no other third group).

The choice of genera within the Marantaceae was based on Andersson's (1977) revision of Ischnosiphon. Selection of species within each of the genera was based on availability of flowering material. Three species of Calathea were chosen to represent different sections of this large genus (Schumann, 1902). Collectors, collection numbers and location of voucher specimens are given in Table 1.

MATERIALS AND METHODS-FlowerIng material was collected both in Costa Rica, during the summer of 1978, and from plants cultivated in the Duke University greenhouses. Dr. G. Prance was kind enough to supply material of Monotagma plurispicatum from Brazil.

The floral apices for epi-illumination study and paraffin sections were first fixed in formalin-acetic acid-alcohol (FAA: $50 \mathrm{ml} \mathrm{95 \%}$ 
TABLE 1. Species examined

\begin{tabular}{clc}
\multicolumn{1}{c}{ Species } & \multicolumn{1}{c}{$\begin{array}{c}\text { Collection } \\
\text { no. }\end{array}$} & $\begin{array}{c}\text { Voucher } \\
\text { location }\end{array}$ \\
\hline $\begin{array}{c}\text { Calathea lancifolia } \\
\text { Boom }\end{array}$ & KirchOff 281 & DUKE \\
$\begin{array}{c}\text { Calathea leopardinia } \\
\text { (Bull) Reg. } \\
\text { Calathea vinosa } \\
\text { Kennedy }\end{array}$ & $\begin{array}{l}\text { Kres s 78-1001 } \\
\text { KirchOff } 381\end{array}$ & DU KE \\
$\begin{array}{c}\text { Ischnosiphon elegans } \\
\text { Standl. }\end{array}$ & Kress 77-879 & DUKE \\
$\begin{array}{c}\text { Marantochloa purpurea } \\
\text { (Rid1.) M. Redh. }\end{array}$ & Kress 78-896 & DUKE \\
$\begin{array}{c}\text { Monotagma plurispicatum } 78-894 \\
\text { (Ko ernicke) Schum. }\end{array}$ & Prance 26320 & DUKE \\
$\begin{array}{c}\text { Pleiostachya pruinosa } \\
\text { (Reg.) Schum. }\end{array}$ & Kress 78-916 & DUKE \\
$\begin{array}{c}\text { Canna indica } \text { L. } \\
\text { Kans }\end{array}$ & Kress 76-541 & DUKE \\
\hline
\end{tabular}

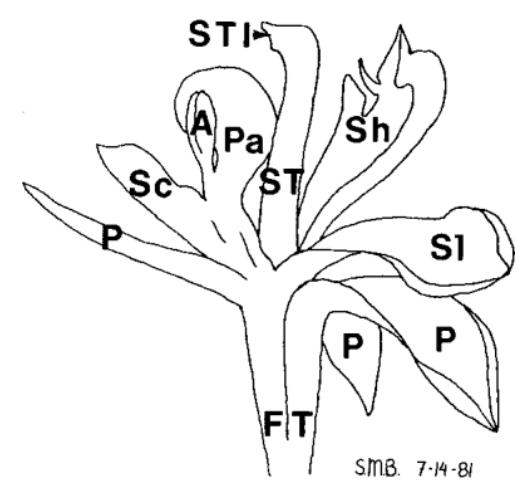

Fig. 1. Diagrams of an imaginary species of the Marantaceae showing the relationships of the floral parts. P, petals; FT, floral tube; C, sepals; 0, ovary; Sc, callose staminode; $\mathrm{A}$, anther; $\mathrm{Pa}$, petaloid appendage to anther; ST, style; STI, stigma; Sh, hooded staminode; $\mathrm{Si}$, outer staminode.

in the form of the androecial members. According to Pai (1965) the androecium of both families is composed of two trimerous whorls. The inner whorl contains the functional anther, which is reduced to two loculi with an associated petaloid appendage (Fig. 1), and two petaloid staminodes. In the Cannaceae these petaloid members are the labellum and the inner staminode. In the Marantaceae they are the hooded staminode, which encloses the style and stigma before pollination, and a callose staminode (Fig. 1) on which the tripped style rests after pollination (Fig. 2).

The outer androecial whorl is trimerous in construction but is seldom represented by three mature structures (for exceptions, see Costerus, 1916). The members of this whorl are always petaloid and are referred to as the outer staminodes. For most of the species included in this study (Canna indica, Calathea vinosa, C. leopardinia, $C$ lancifolia, Monotagma plurispicatum, Pleiostachya pruinosa, Ischnosiphon elegans) only one member of this whorl is fully developed (Fig. 1). Marantochloa purpurea, however, has two.

The ovary in both families is inferior and trilocular. In the Cannaceae each locule contains two series of anatropous ovules while the Marantaceae possess, at most, one anatropous to campylotropous ovule per locule. For many genera of the Marantaceae (including Ischnosiphon, Pleiostachya, and Monotagma) ovules are not produced in two of the three loculi, leaving only one ovule per flower.

The corolla, androecium and style of both families are fused into a floral tube of variable length. The sepals do not contribute to this 


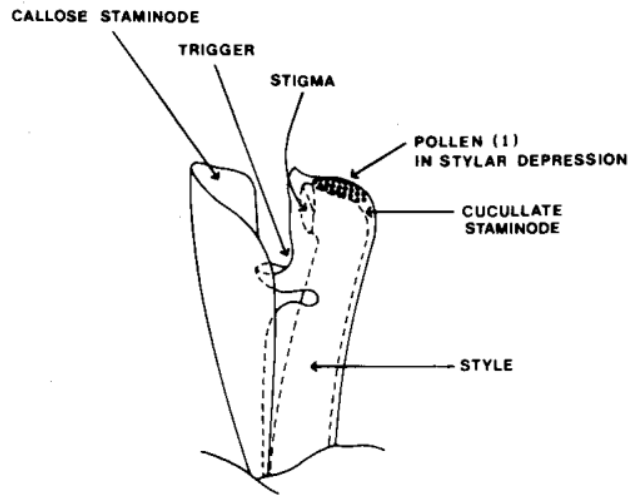

1. UNTRIPPED FLOWER

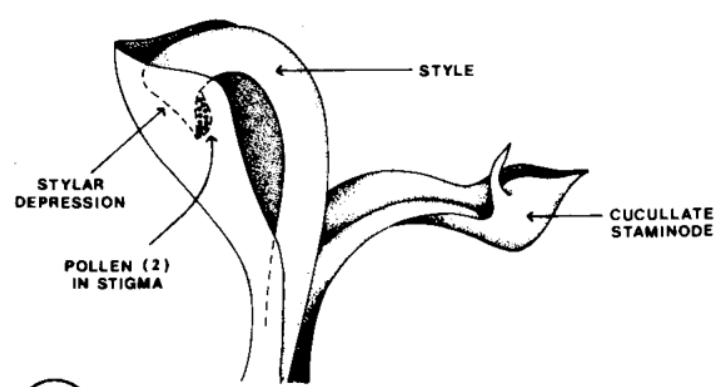

2

2. TRIPPED, POLLINATEO FLOWER

Fig. 2. Diagrams showing the relationships of the eallose staminode, hooded (cucullate) staminode, stigma and style before (diagram 1, untripped) and after (diagram 2, tripped) pollination. Stylar depression $=$ stamp (Andersson, I 98 1). Figure from Kennedy ( 1977 ).

tube, becoming free directly above the ovary (Fig. 1).

The shape of the stigma and style is distinct in the two families. In the Cannaceae it is a petaloid structure with a terminal stigma. In the Marantaceae the distal portion of the style is sharply bent, displacing the stigma to a lateral position, facing the callose staminode (Fig. $2)$. The flattened, or depressed, terminal portion of the style, the stamp (Andersson, 1981), receives the pollen prior to anthesis (Kennedy, 1977; Andersson, 1981).

Inflorescence structure in the Marantaceae has been described by Eichler (1875) and by Andersson (1976) and will not be reviewed here except when pertinent to the developmental descriptions which follow. Each bract on the florescence (an indeterminate flowering shoot bearing lateral flowers or groups of flowers and forming a repeated unit of an inflorescence, Weberling, 1965) subtends a sympodial system of axes (the florescence component, Andersson, 1976) each bearing a
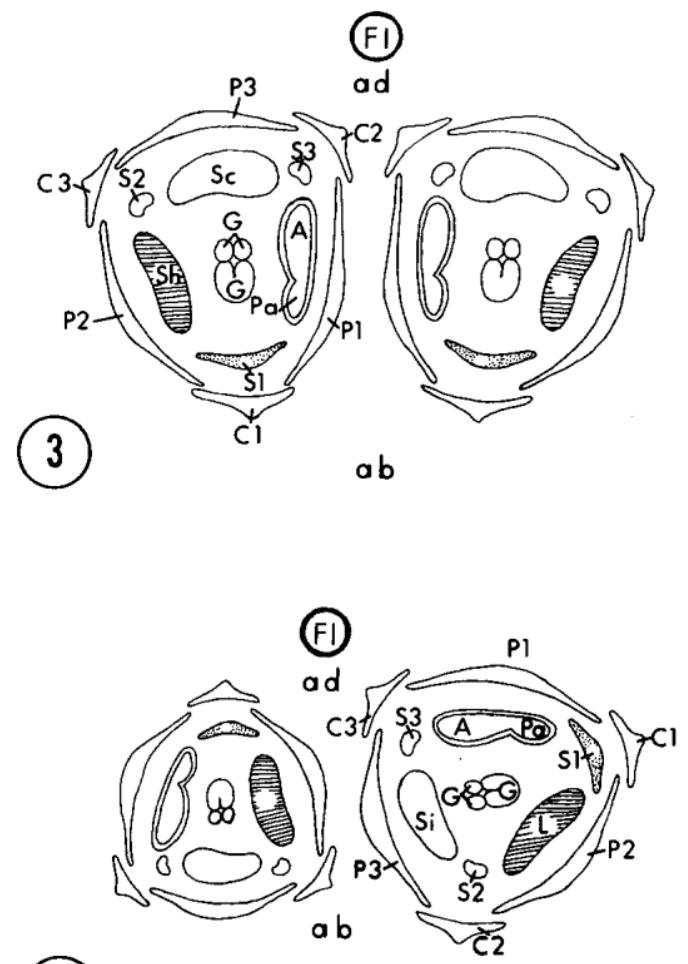

4

;1

Fig. 3, 4. 3. Diagram of the paired flowers of the Marantaceae. F I , floreseence axis; ab, abaxial; ad, adaxial; C I, abaxial sepal; C2, adaxial sepal, C3, lateral sepal; PI, lateral petal; P2, abaxial petal; P3, adaxial petal; A, anther; Pa, petaloid appendage of anther; Sh, hooded staminode; Sc, eallose staminode; S 1, abaxial outer staminode; S2, lateral outer staminode; S3, adaxial outer staminode; G, gynoeeial primordium. 4. Diagram of the paired flowers of the Cannaceae. F 1 , florescenee axis; ab, abaxial; ad, adaxial; C 1 , lateral sepal; C2, abaxial sepal; C3, adaxial sepal; P I , adaxial petal; P2, abaxial petal; P3, lateral petal; A, anther; Pa, petaloid appendage of anther; L, labellum; $\mathrm{Si}$, inner staminode; SI , lateral outer staminode; S2, abaxial outer staminode; S3, adaxial outer staminode; G, gynoecial primordium.

pair of flowers (the cymule). The flowers of a pair are mirror images of each other and are oriented so that the functional stamens are adjacent to each other (Fig. 3). This orientation results in one sepal lying distal to the main florescence axis (the abaxial sepal) one proximal (the adaxial sepal) and one midway between these two in the lateral plane (the lateral sepal). In a similar manner abaxial, adaxial and lateral petals can be identified (Fig. 3). The functional stamen is opposite the lateral petal, the hooded staminode opposite the abaxial petal, and the callose staminode opposite the adaxial petal. When a single member of the 
outer androecial whorl is present it is located opposite the abaxial sepal. It is, thus, referred to as the abaxial outer staminode. When two members of the outer whorl are present the second is opposite the adaxial sepal and is designated the adaxial outer staminode. The third position of the outer androecial whorl is vacant at maturity. However, the primordium which occupies this position during early development is designated the lateral outer staminode as it is opposite the lateral sepal (Fig. 3).

Each florescence of the Cannaceae consists of a main axis with spirally arranged bracts each of which subtends a single pair of flowers. In Canna indica one flower of this pair generally does not complete development. In Can$n a$ the flowers of a pair are not mirror images of one another and the floral orientation with respect to the florescence axis is also different from the Marantaceae (Fig. 4). The stamen of the flower which most often completes development is adjacent to the florescence axis. The other flower is oriented so that the solitary outer staminode is adjacent to the floral axis. It is, thus, as if this second flower were rotated approximately $70^{\circ}$ counterclockwise with respect to the first (Fig. 4).

As in the Marantaceae it is possible to identify abaxial, adaxial, and lateral perianth members (Fig. 4). These terms, however, do not designate organs which are homologous to the organs of the same name in the Marantaceae. They are purely descriptive terms useful only in locating a specific organ relative to the florescence axis. The homologies of the floral organs will be taken up in the discussion.

Three other terms require clarification. Ventral and dorsal are used to indicate a side (flank) of a specific primordium within a flower. The ventral flank refers to the inner portion of a primordium, adjacent to the central axis of the flower, while the dorsal flank refers to the outer portion of a primordium. The term median plane will be used to designate the longitudinal plane which passes through the center of the florescence axis and the subtending bract of the cymule. The paired flowers of the Marantaceae, thus, lie on either side of the median plane.

Organogenesis_Ischnosiphon elegans: Sequence of initiation - Apex becomes truncate; abaxial sepal; adaxial sepal; lateral sepal; ring primordium; stamen and petal; hooded staminode and petal; callose staminode and petal; abaxial outer staminode; lateral outer staminode; adaxial outer staminode; gynoecium.

Cymule - The double flowered cymule originates from a single apical meristem (Fig. 5) with a tunica-corpus structure (Fig. 6). This apex enlarges and divides medianly to produce two asymmetric floral apices, each of which produces a mature flower. Lateral organ production begins with cell divisions in the lateral flank of each apex away from the other flower of the pair (Fig. 8). Although cell divisions predominate in this flank they are taking place throughout the whole of each apex. They give rise to a truncate floral primordium set at an angle to the vertical axis of the cymule (Fig. 7, 8 ). Continued circumferential growth of this apex produces a ring primordium which gives rise to the floral cup, corolla and androecium.

Calyx - The first lateral organs to be produced are the sepals. The first and second sepals arise, in rapid succession, on the abaxial and adaxial flanks of the apex, respectively (Fig. 9). The sepal formed in the lateral position arises last (Fig. 9, 10). All of the members of this whorl are initiated through periclinal divisions in the first and second corpus layers (Fig. 11). Growth of the ring primordium continues during the process of sepal formation to produce an asymmetric ring of tissue. Even at this early stage of growth the region which gives rise to the functional stamen is slightly larger than the rest of the primordium (Fig. 12).

Stamen and petal-The members of the corolla and inner androecium do not arise directly from the floral meristem, but from portions of the ring primordium. The functional stamen with its attached petaloid appendage first becomes distinct from its adjacent petal (Fig. 10, 13) followed by the formation of the hooded staminode and petal, and the callose staminode and petal (Fig. 14). The stamen is formed on the ventral flank of the common stamen-petal primordium (part of the ring primordium) through periclinal and anticlinal cell divisions in this region (Fig. 15). The stamen first becomes apparent in the region of the petaloid appendage and then in the region of anther formation (Fig. 10). The terminal portion of the common primordium gives rise to the petal. At a later stage of stamen growth it is evident that the lower (proximal) portion of the common primordium does not go into the formation of the anther or petal. Rather it forms the primordial region (similar to the floral cup of Kaplan, 1967) which becomes part of the floral tube and ovary (Fig. 16). Growth in this region is intercalary.

Hooded staminode and petal-The hooded staminode and petal are formed through the initiation of two growth centers in the ventral and dorsal flanks of the common primordium. Cell divisions in these regions produce a truncate, slightly two-humped, primordium (Fig. 


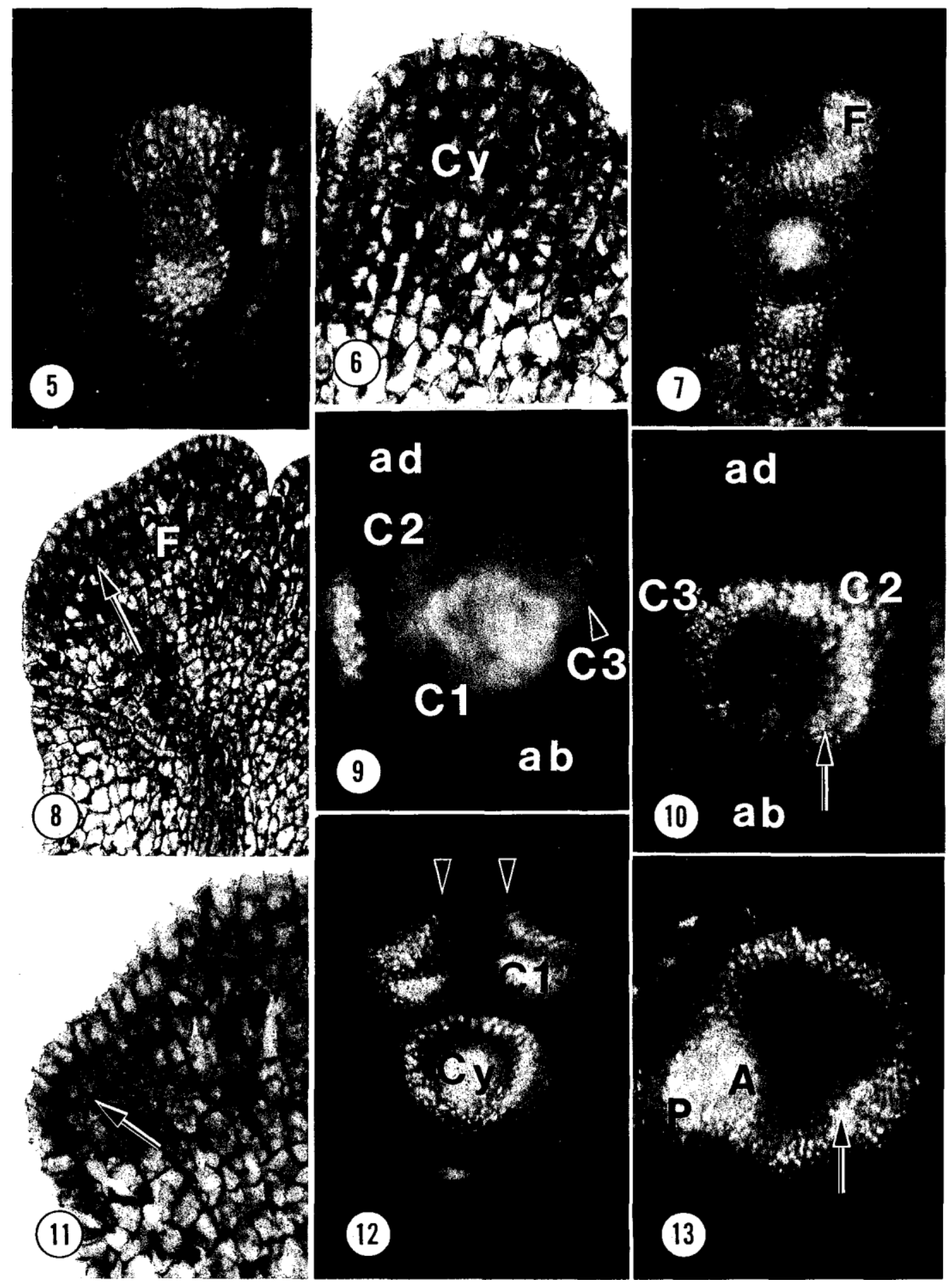

Fig. 5-13. organogenesis of Ischnosiphon elegans. 5. Apical meristem (Cy) which gives rise to a double flowered cymule. X294. 6. Longitudinal section of a young cymule primordium (Cy) showing tunica-corpus structure. X588. 7. An abaxial view of a two-flowered cymule with floral primordia (F) set at an angle to the vertical. X181. 8. Section of one of the floral primordia (F) shown in Fig. 7. The plane of section is parallel to the plane of the photograph in Fig. 7. The arrow indicates a region of cell division that causes the apex to flatten. X339. 9. Floral apex showing order of sepal formation. Cl, abaxial (ab) sepal; C2, adaxial (ad) sepal; C3, lateral sepal. X233. 10. Floral apex showing the adaxial (C2) and lateral (C3) sepals. The abaxial sepal is below the plane of focus. The arrow indicates the region of petaloid appendage formation. X233. 11. Longitudinal section showing the region of sepal formation (arrow). X727. 12. Abaxial side of a two-flowered cymule. Arrows indicate the regions which produce the stamen. C1, abaxial sepal; $\mathrm{Cy}$, cymule primordium. X163. 13. Floral apex with distinct petal (P) and stamen (A) primordia. Arrow indicates the region where hooded staminode formation begins. X219. 

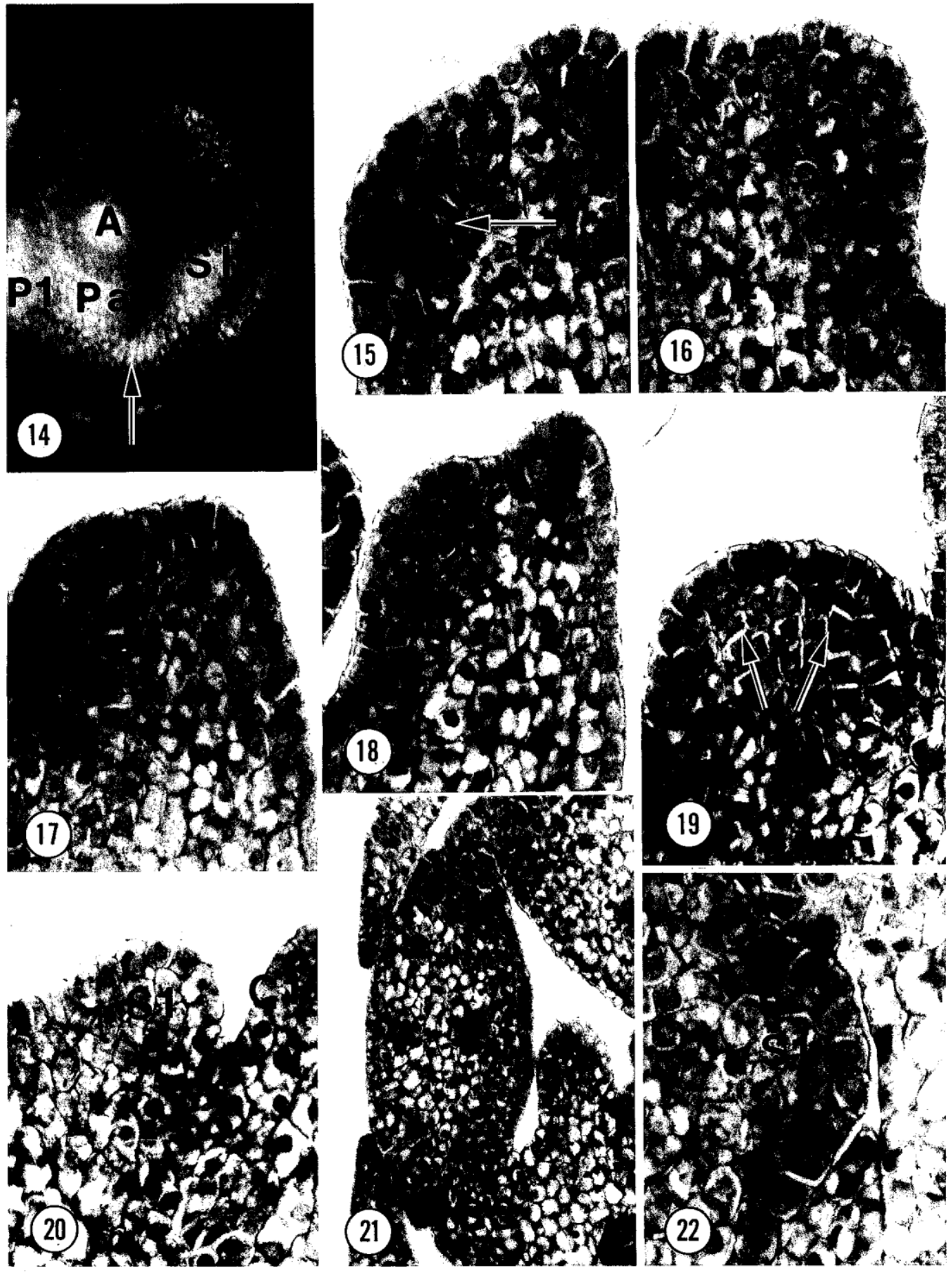

Fig. 14-22. Ischnosiphon elegans. 14. Sequence of formation (P1-3) of the inner androecial whorl. Arrow shows the region of abaxial outer staminode formation. A, anther; Pa, petaloid appendage; PI, lateral petal; P2, abaxial petal; P3, adaxial petal; Sc, callose staminode; Sh, hooded staminode. X242. 15. Longitudinal section showing the region of cell division (arrow) on the flank of the stamen-petal common primordium. X727. 16. Longitudinal section of petal (P), anther (A) and floral tube (FT). X640. 17. Longitudinal section of the truncate hooded staminode (Sh) - petal (P) primordium. X623. 18. Longitudinal section showing a later stage of hooded staminode (Sh) - petal (P) separation. X588.19. Longitudinal section of eallose staminode-petal eommon primordium. Arrows indicate regions of eell division. X678. 20. Longitudinal seetion of young abaxial outer staminode primordium (S I). CI, abaxial sepal. X657. 21. Cross section at the level of the outer androeeial whorl showing vacuolation of the adaxial outer staminode (S3). S2, lateral outer staminode. X477. 22. Cross section of the abaxial outer staminode (S1) from the same bud as Fig. 21. X865. 


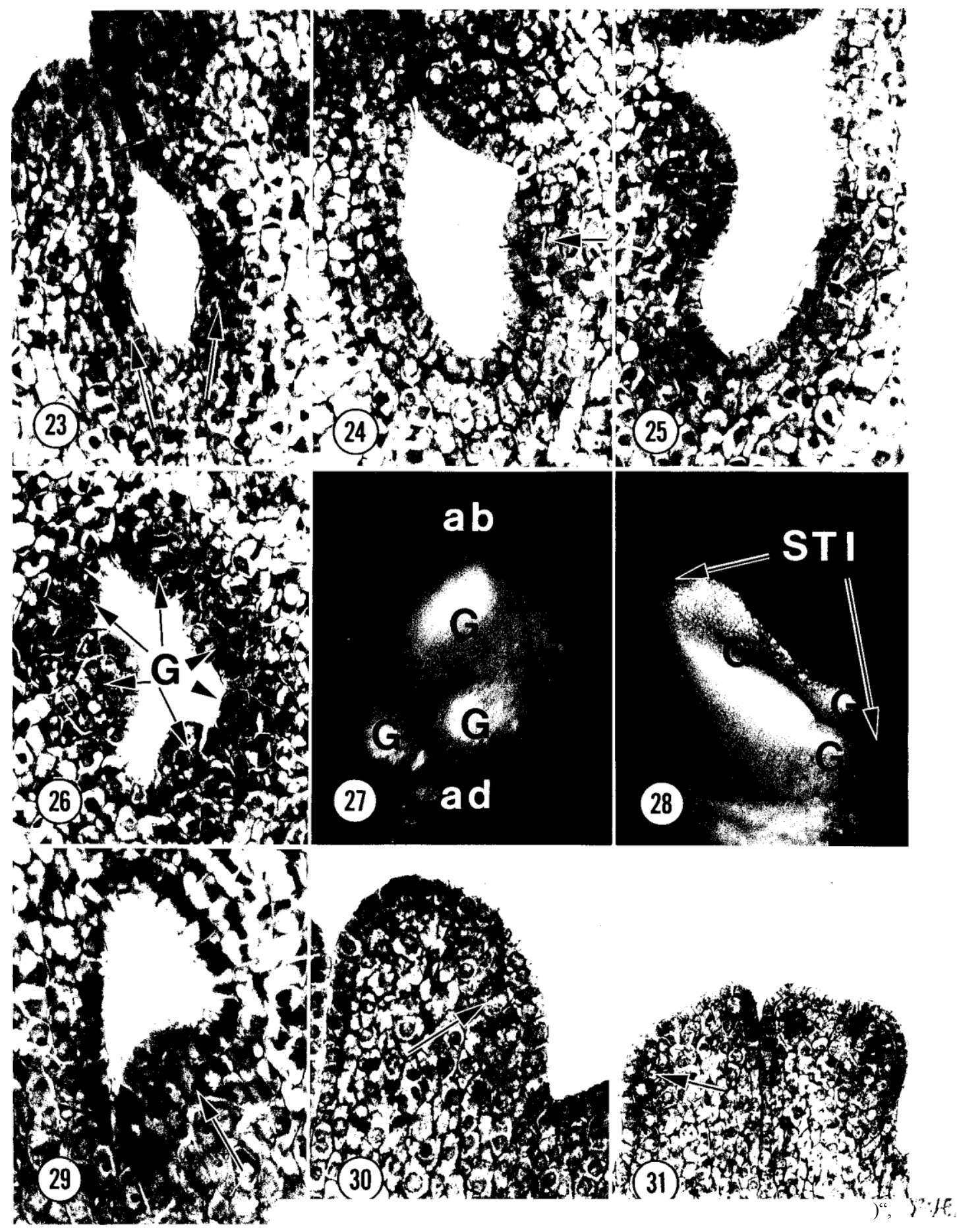

Fig. 23-31. 23-27, 29. Ischnosiphon elegans. 28. Calathea vinosa. 30-31. Pleiostachya pruinosa. 23. Longitudinal seetion showing residual meristem (arrows) in the ventral margin of the floral cup. X498. 24. Longitudinal section showing formation of a gynoecial primordium. The arrow indicates a periclinal cell division. X519. 25. Longitudinal section of a later stage in the growth of a gynoeeial primordium $(\mathrm{G})$. Cell divisions are visible in the subsurface layers. X502. 26. Cross section showing three conduplicate gynoecial primordia (G) which produce the septa. X467. 27. Top view of three gynoecial primordia ( $\mathrm{G}$, one conduplieate) whieh form the stigma and style. All other floral parts have been removed. ab, abaxial; ad, adaxial. X224. 28. Lateral view of the fusion of the three gynoecial primordia $(\mathrm{G})$ which form the stigma (STI) and style. X111. 29. Longitudinal section illustrating ovule initiation. The arrow shows a region of anticlinal cell expansion. X779. 30. Longitudinal section of the anther-petal eommon primordium. Arrow indicates the region of antielinal expansion. X554. 31. Longitudinal section of the anther (A) and petal (P) primordia in two adjaeent flowers. Arrow indicates a recent periclinal cell division. X329. 
17). Continued growth of the ventral and dorsal flanks gives rise to the staminode and petal respectively (Fig. 18). In surface view it is clear that cell division begins in the abaxial portion of the common primordium and extends adaxially (Fig. 13).

Callose staminode and petal-The callose staminode and its associated petal are initiated through periclinal divisions in the ventral and dorsal flanks of the common callose staminode-petal primordium (Fig. 14, 19). Continued growth of these regions first causes the primordium to flatten and then, gives rise to the callose staminode ventrally and the petal dorsally.

Outer androecial whorl- The outer (antisepalous) androecial whorl is formed in a sequence that continues the spiral of the inner whorl: abaxial outer staminode; lateral outer staminode; adaxial outer staminode. Due to the shape of the floral apex at this stage these staminodes are formed on the ring primordium in the positions not occupied by the inner androecial members. The first signs that they have begun growth are slight protuberances at these positions on the ring primordium (Fig. 14). In longitudinal section they are visible as small outgrowths opposite the sepals (Fig. 20). As development continues the lateral and adaxial outer staminodes lose their meristematic character and stop growing. Vacuolation is first apparent in the adaxial outer staminode and then in the lateral staminode (Fig. 21). Throughout this process the abaxial staminode retains its meristematic character (Fig. 22). Its continued development produces the solitary outer staminode present in the mature flower.

Gynoecium - The gynoecium is the last floral organ to be initiated on the apex. It is first visible as a residual meristem which appears in the inner margin of the floral cup (Fig. 23). Soon after this meristem is visible, anticlinal cell expansion begins in the two outer cell layers. This is followed by periclinal and oblique divisions in the subsurface layers (Fig. 24, 25). As growth continues, cell divisions extend proximally to produce the septal primordia (Fig. 26). Distal expansion of the gynoecial primordia produces the stigma and style (Fig. 27, 28). Of the three primordia which contribute to the stigma and style the largest has a conduplicate structure and faces adaxially (Fig. 27 ). The remaining two primordia are simple mounds which fuse to the adaxial margins of the first soon after they arise (Fig. 27, 28). Because of unequal growth of these three primordia the largest, conduplicate one contributes approximately two-thirds of the stylar tissue, while the smaller ones contribute the remaining one-third. In a like manner, the more rapid growth of the conduplicate primordium causes it to form the distal portion of the stigma while the proximal portion is formed by the remaining two primordia (Fig. 28).

The single ovule is initiated basally, through a process very similar to that which gives rise to the septal-style primordia: anticlinal cell expansion in the outermost layers of the corpus, followed by periclinal cell divisions in the same area (Fig. 29). In genera, such as Ischnosiphon, which form only one ovule per flower this ovule is found in the locule enclosed by the larger of the three septal-style primordia.

The additional species of Marantaceae which were investigated in this study show a basically similar pattern of organogenesis to that found in Ischnosiphon elegans. For this reason the organogenesis of these species will not be discussed in detail. Only the organogenesis of those species and floral parts which could not easily be summarized in tabular form are discussed below. Organogenesis of all of the other species of the Marantaceae is presented in Table 2 . In both cases only the differences with Ischnosiphon elegans are presented. Unless otherwise stated all floral organs show the same pattern of organogenesis as found in I. elegans.

Marantochloa purpurea: Cymule The separation of the paired flower primordia was not observed. Ring primordia formation is as in Ischnosiphon elegans.

Outer androecial whorl- The formation of the outer androecial whorl is identical to that of Ischnosiphon elegans. However, soon after initiation the adaxial staminode begins to grow rapidly and is soon larger than the earlierformed lateral staminode (Fig. 33). This difference in growth reflects the fact that the adaxial staminode develops into a mature floral organ while the lateral staminode ceases development soon after initiation.

Calathea vinosa: Gynoecium - The patterns of initiation of the gynoecial primordia and ovules are the same as in Ischnosiphon elegans. One ovule is formed in each locule in all species of Calathea. The inner and outer integuments are initiated, in that order, on the sides of the ovule primordia. The inner integument is initiated through periclinal divisions in the protoderm (Fig. 35). The outer integument is initiated soon after the inner, through anticlinal cell expansion and periclinal cell division in the two outermost layers of the ovule primordium. Cell division begins in the outermost layer before it begins in the inner (Fig. 36). The integuments are the only parts of the flower, 


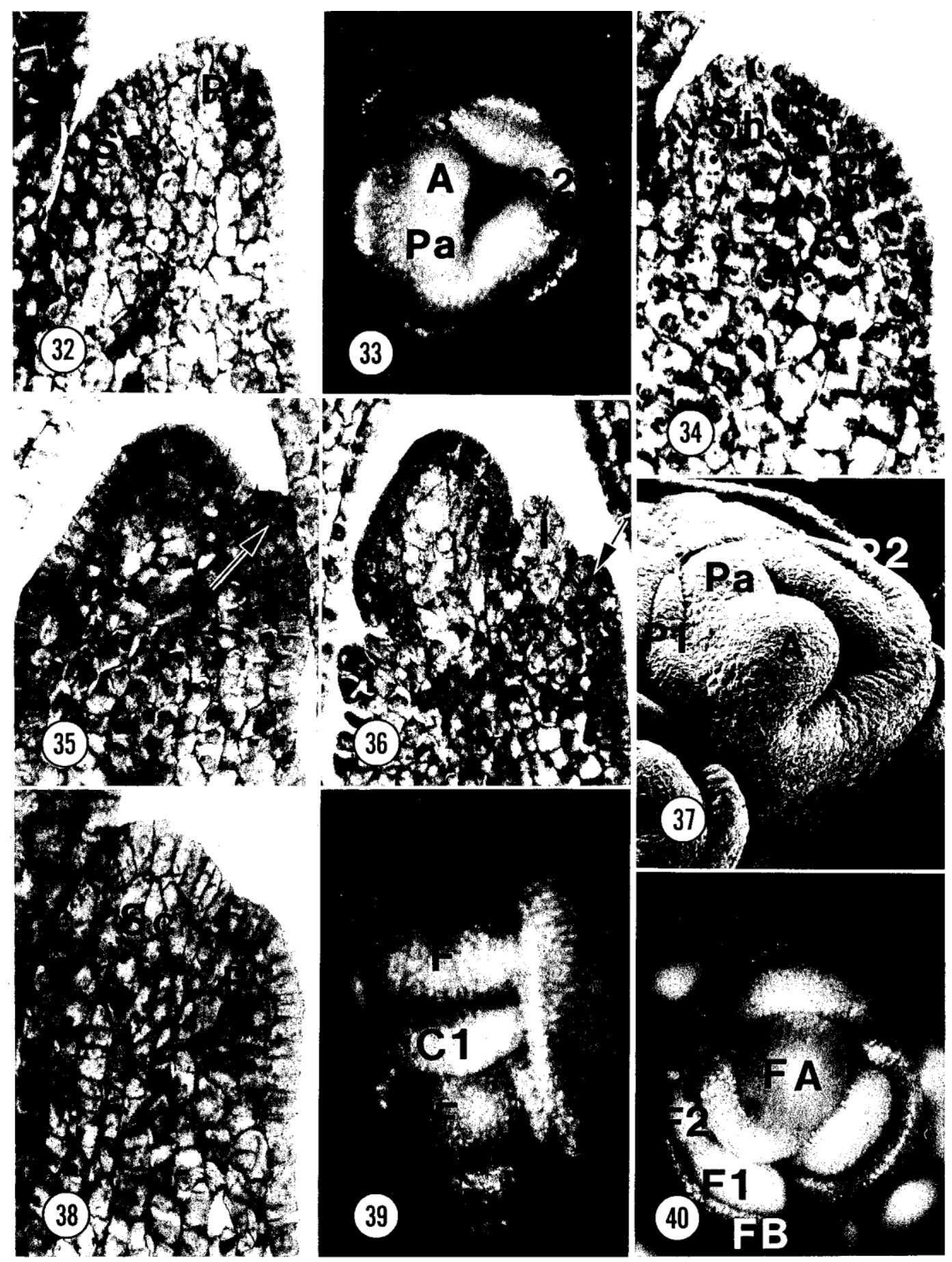

Fig. 32-40. 32-33. Marantochloa purpurea. 34. Calathea leopardinia. 35-36. Calathea vinosa. 37-38. Calathea lancifolia. 39. Monotagma plurispicatum. 40. Canna indica. 32. Longitudinal section showing the initiation of the eallose staminode (Se) in the inner flank of the common primordium. P, petal. X709. 33. Floral primordium showing the initiation and development of the adaxial outer staminode (S3). A, anther; Pa, petaloid appendage; S2, lateral outer staminode. X191. 34. Longitudinal seetion showing separation of the hooded staminode (Sh) - petal (P) primordium. X541. 35. Longitudinal section showing initiation of the inner integument. The arrow indicates a periclinal division in the protoderm. X588. 36. Longitudinal section showing initiation of the outer integument (0). The arrow indicates a region of cell division in the protoderm. I, inner integument. X571. 37. SEM showing displacement of the lateral petal (P1) and relative sizes of the anther (A) and petaloid appendage (Pa). P2, abaxial petal. X164. 38. Longitudinal seetion showing separation of the callose staminode $(\mathrm{Sc})$ - petal $(\mathrm{P})$ primordium. X657. 39. Abaxial view of floreseenee eomponent with two floral primordia (F) at different stages of growth. The abaxial sepal (C1) of the upper flower has begun to reflex over the lower flower. X130. 40. Top view of florescence primordium showing initiation of flower pairs $(\mathrm{F} 1, \mathrm{~F} 2)$ in the axils of the floreseenee bracts (FB). B, bract; FA, florescenee apex. X106. 
TABLE 2. Summary of floral development in six species of Marantaceaea

\begin{tabular}{|c|c|c|}
\hline Species & Stamen and petal & $\begin{array}{c}\text { Hooded staminode } \\
\text { and petal }\end{array}$ \\
\hline Pleiostachya pruinosa & $\begin{array}{l}\text { S initiated in ventral flank of } \\
\mathrm{CP} \text { through antielinal cell } \\
\text { expansion (Fig. 30) and peri- } \\
\text { elinal cell division (Fig. } 31 \text { ) } \\
\text { in the outermost eorpus lay- } \\
\text { er. }\end{array}$ & As in I. elegans \\
\hline Marantochloa purpurea & $\begin{array}{l}\text { Two growth centers initiate in } \\
\text { the ventral (stamen) and } \\
\text { dorsal (petal) flanks of CP. } \\
\text { The Pa arises before and } \\
\text { separately from the A to } \\
\text { yield separate, subequal, pri- } \\
\text { mordia on the ventral flank } \\
\text { of the CP. }\end{array}$ & As in I. elegans \\
\hline Calathea leopardinia & $\begin{array}{l}\text { As in Marantochloa purpurea. } \\
\text { only one stamen primor- } \\
\text { dium is produced and gives } \\
\text { rise to both the A and Pa. } \\
\text { Widening of the } \mathrm{CP} \text { begins } \\
\text { in the region of the A and } \\
\text { extends abaxially to the re- } \\
\text { gion of the } \mathrm{Pa} \text {. The larger } \\
\text { part of the } \mathrm{CP} \text { goes to form }\end{array}$ & $\begin{array}{l}\text { As in I. elegans. A } \\
\text { greater amount } \\
\text { of growth in the } \\
\text { ventral flank of } \\
\text { the CP produces } \\
\text { a truncate pri- } \\
\text { mordium which } \\
\text { is larger ventral- } \\
\text { ly (Fig. 34). }\end{array}$ \\
\hline
\end{tabular}

Calathea vinosa

$$
\text { the } S \text {. }
$$

As in Marantochloa purpurea. It has proven impossible to determine which of the two stamen primordia is formed first.

Calathea lancifolia

Two growth centers are initiated in the ventral (stamen) and dorsal (petal) flanks of the CP. The A appears before and separately from the $\mathrm{Pa}$. Division of the $\mathrm{CP}$ is unequal, the major portion going to form the S. Rapid growth of the $\mathrm{S}$ displaees the $\mathrm{P}$ to a lateral position early in development (Fig. 37)

Monotagma plurispicatum

\section{As in I. elegans} only epi-illumination observations were possible. It has proven impossible to determine which of the two stamen primordia is formed first although the A appears larger than the $\mathrm{Pa}$ at an early

\section{As in I. elegans. Growth in the ventral flank of the CP exeeeds growth in the dorsal whieh causes the $\mathrm{P}$ to appear in a lat- eral position on the Sh.}

As in I. elegans. At an early stage of growth the Sh appears larger than the P.
Sc initiated in the ventral flank of the $\mathrm{CP}$ thrOugh periclinal divisiOns in the outer cOrpus (Fig. 32)

As in I. elegans

\begin{abstract}
As in I. elegans. only epi-illumination observations were possible.

As in I. elegans. Growth in the ventral flank of the CP exeeeds growth in the dorsal displaeing the $\mathrm{P}$ to an almost lateral position on the $\mathrm{Se}$ (Fig. 38).
\end{abstract}

As in I. elegans. only epi-illumination observations were possible. staoe of orowth

\footnotetext{
a When similarities exist between the development of an organ in two species the name of the similar species is given first followed by a description of the differences found in the two species. CP, common primordium; $\mathrm{P}$, petal; S, stamen; A, anther; $\mathrm{Pa}$, petaloid appendage; Sh, hooded staminode; Sc, callose staminode.
}

in the Marantaceae, whose initiation involves cell divisions in the outermost cell layef.

Monotagma plurispicatum: Cymule_A characteristic feature of the genus Monotagma is the possession of one-flowered cymules. The stages of cymule initiation reflect this aspect of mature structure in that the cymule primordium does not divide, but gives rise to a solitary floral apex (Fig. 39). The initial growth of this apex, which serves to flatten it and begins the formation of the ring primordium, takes place in the abaxial margin, away from the florescence axis. In Ischnosiphon elegans growth of the floral apices begins in the lateral margins, away from the other flower of the pair.

Calyx - In sequence and region of sepal ini- 


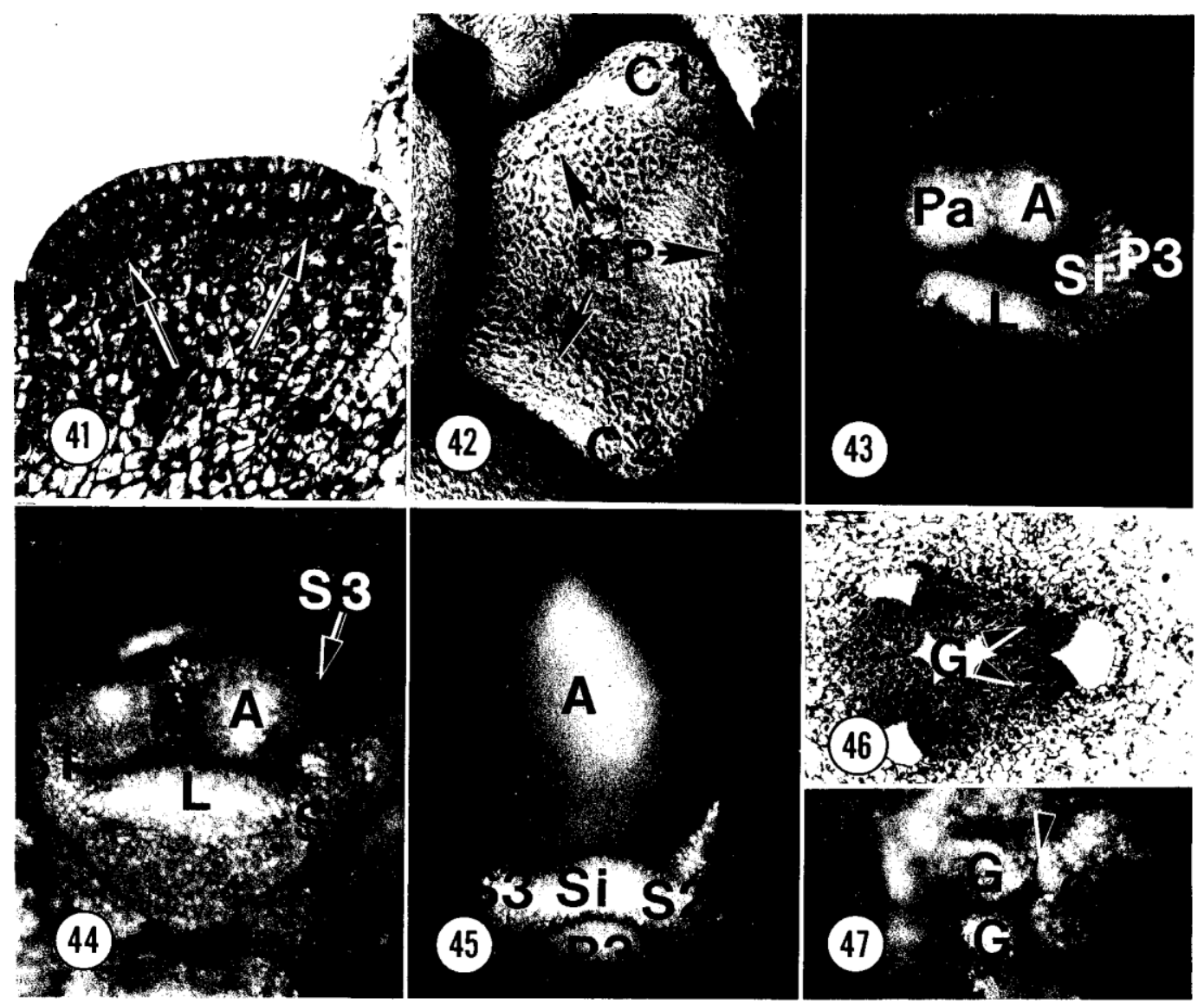

Fig. 41-47. Canna indica. 41. Longitudinal section of young floral apex. Arrows indicate the regions of cell division in the medial flanks. X276. 42. SEM of young floral primordium showing initiation of the lateral (C1) and abaxial (C2) sepals, and of the ring primordium (RP). The florescence axis is the upper left in this picture. X256. 43. Flower primordium showing showing double stamen primordium and inner staminode ( $\mathrm{Si}$ ) formation. A, anther; L, labellum; $\mathrm{Pa}$, petaloid appendage; P3, lateral petal. X200. 44. Formation of the outer androecial whorl on the ring primordium. A, anther; L, labellum; S 1 , lateral outer staminode; S2, abaxial outer staminode; S3, adaxial outer staminode. X131. 45. View of the lateral side of the floral primordium after gynoecial initiation. Sepals and two petals have been removed. Note that the lateral petal is much smaller than the inner staminode. A, anther; P3, lateral petal; S2, abaxial outer staminode; S3, adaxial outer staminode. X128. 46. Cross section showing the fusion of the conduplicate gynoecial primordia (one labeled, G), proximal to the site of initiation, to produce the septa. X141. 47. Top view of three gynoecial primordia $(\mathrm{G}$, one conduplicate) which fuse to form the stigma and style. Arrow indicates the region of fusion. X108.

tiation Monotagma plurispicatum shows the same pattern as Ischnosiphon elegans. However, soon after the abaxial sepal is initiated it begins to reflex so that it partially covers the next flower of the sympodium (Fig. 39). No other species studied shows this pattern of abaxial sepal development.

Canna indica: Because of the difference in the orientation of the flower with respect to the florescence axis in the Cannaceae and Marantaceae the terms used below do not refer to the same structures as do the corresponding terms in the Marantaceae. A comparison of the initiation patterns in these two families is in cluded in the Discussion section, which immediately follows this description.

Sequence of initiation-Apex becomes truncate; lateral sepal; abaxial sepal; adaxial sepal; ring primordium; stamen and petal; labellum and petal; inner staminode and petal; lateral outer staminode; abaxial outer staminode; adaxial outer staminode; gynoecium.

Origin of the flower pair-Each bract on the florescence axis produces, in its axil, a laterally elongated primordium which gives rise to a pair of flowers. The larger of these flowers is produced directly from this primordium, while the smaller arises in the axil of a bract produced 
on the side of the primordium (Fig. 40). The former gives rise to a mature flower while the latter often ceases development while it is still quite small. It is, however, occasionally possible to find the two flowers of a pair fully developed. Unlike the Marantaceae, the paired flowers in the Cannaceae are not mirror images of one another. In the Marantaceae the stamen forms on the lateral portion of the floral apex, adjacent to the other flower of the pair. This results in a medianly symmetrical pair of flowers. In Canna indica the stamen of the larger primordium is produced perpendicular to the medial line of the flower, adjacent to the florescence axis (Fig. 4), while the stamen of the smaller flower arises at approximately a $20^{\circ}$ angle to the medial line (Fig. 4). Thus, if the larger flower were rotated through approximately $70^{\circ}$ (counterclockwise) it would be in the same relationship with respect to the florescence axis as is the smaller flower. To avoid confusion the terms used below all pertain to the development of the larger flower primordium.

A truncate floral apex is produced through cell divisions in the medial flanks of the apex (Fig. 41). Continued cell divisions around the periphery of the apex produce the ring primordium (Fig. 42). Even at this early stage of growth the adaxial portion of this primordium, which gives rise to the stamen, is larger than the rest of the ring primordium.

Calyx - Sepal initiation begins while the above processes are taking place. The sepals are initiated by periclinal and anticlinal divisions in the corpus on the side of the floral apex, and slightly below the ring primordium. The lateral sepal appears first, followed by the abaxial and adaxial sepals in that order (Fig. 42).

Stamen and petal-The common stamenpetal primordium (part of the ring primordium) widens and separates into the stamen and petal due the formation of two growth centers in its ventral and dorsal flanks. The stamen primordium is first apparent in the region which will produce the petaloid appendage and, then, as a separate primordium, in the region of the anther. )In this way, a double stamen primordium aries (Fig. 43). One primordium produces the petaloid appendage while the other gives rise to the anther. The dorsal portion of the common primordium produces the petal (Fig. 43).

Labellum and petal- Cell divisions in the ventral and dorsal flanks of the common primordium give rise to two growth centers that produce the labellum ventrally and the petal dorsally. The labellum appears first on the in ner flank of the common primordium in the region adjacent to the first formed sepal and extends laterally to include the rest of the primordium. There is some variation in the sequence of inner androecial initiation described to this point. An apex was found in which separation of the labellum-petal primordium begins before the anther primordium appears. However, even in this case stamen initiation begins, with the formation of the petaloid appendage, before the formation of the labellum.

Inner staminode and petal-The following description is based only on material examined by epi-illumination light microscopy: the inner staminode is produced on the ventral flank of the common primordium while the dorsal flank and part of the apex of the common primordium produce the petal (Fig. 43). Soon after the inner staminode is produced it appears larger than the petal and remains larger throughout organogenesis (Fig. 45).

Outer androecial whorl-The order of formation of the outer androecial whorl continues the spiral established by the other floral parts: lateral outer staminode; abaxial outer staminode; adaxial outer staminode. Due to the shape of the floral apex at this time, the outer staminodes arise on the ring primordium in the positions not occupied by the inner androecial members. The first signs of these outer staminodes are small protuberances on the ring primordium (Fig. 44). In Canna indica only the lateral outer staminode normally develops into a mature floral organ. However, several flowers with an adaxial outer staminode have been observed.

Gynoecium - The gynoecium is first visible as a residual meristem which appears in the inner margin of the floral cup after all other floral organs have been initiated. The primordia which give rise to the septa and the stigmastyle appear on the distal margin of the floral cup, opposite the outer androecial members. They arise through a process of anticlinal cell expansion in the tunica and first one or two corpus layers, followed by cell divisions in the corpus.

Proximal to the site of initiation the gynoecial primordia become conduplicate and produce the septa through marginal fusion of adjacent primordia (Fig. 46). Distal to the initiation site only one of the three primordia remains conduplicate while the others appear as undivided outgrowths. The two smaller primordia fuse to the margins of the larger, conduplicate, one (Fig. 47) to produce a single large primordium which goes on to form the stigma and style.

The ovules are initiated axially in each locule 
through anticlinal cell expansion in the tunica, and periclinal divisions in the first layer of the corpus.

DISCUSSION Homologies of theflower in the Marantaceae and Cannaceae-The main problem in determining the homologies of the floral parts is the interpretation of the androecium. The most widely accepted interpretation of flower structure in the Marantaceae, and the one supported by this study, is that the inner androecial whorl consists of the fertile stamen with its attached petaloid appendage, the hooded staminode, and the callose staminode. The outer whorl is then composed of one or two petaloid staminodes depending on the genus (Eichler, 1883; Holttum, 1951; Pai, 1965; Tilak and Pai, 1966, 1968, 1970). The existence of these two whorls is clearly demonstrated in the developmental sequences described here. If we ignore the perianth for the moment, the sequence of initiation is: fertile stamen; hooded staminode; callose staminode; abaxial outer staminode; lateral outer staminode; adaxial outer staminode. Although the inner whorl appears before the outer, this poses no problem to the above interpretation as the members of the inner whorl are, both in position and development, anti-petalous, as is common for the inner androecium.

The interpretation of the androecium of the Cannaceae has sparked much more debate than has that of the Marantaceae. Payer (1857), on the basis of development, interpreted the androecium of Canna as consisting of a single anti-petalous whorl. The stages of development described by Payer are similar to those described here, with two exceptions. First, he states that the petals are initiated simultaneously and are formed independently of the inner androecium. The developmental patterns described here indicate that the petals are initiated sequentially, not simultaneously, their initiation being tied to that of the inner androecium. Second, Payer derives all the staminodes in the mature flower from divisions of the primordia formed opposite the petals. For instance, he derives the lateral outer staminode (Fig. 44) fromp. division of the labellum primordium and the adaxial outer staminode from a division of the inner staminode primordium. He does not mention a primordium forming in the abaxial position of the outer whorl between the labellum and inner staminode (Fig. 44). From a consideration of the developmental patterns presented here it is clear that Payer has simply mistaken the initiation of the outer androecial whorl for divisions in the inner. In reality two whorls are formed.
Eichler (1873) postulates that the labellum and functional stamen, along with two or three staminodes, united at the base with the stamen, represent the inner whorl. In this view the outer androecium is also completely lacking. This interpretation is derived from a study, and misinterpretation, of floral development.

After the formation of the stamen and labellum Eichler describes the initiation of two primordia to the right and left of the stamen primordium. Although he considers both to be members of the inner whorl only the one formed on the left actually is. This is the primordium of the inner staminode (Fig. 43). The right primordium is a member of the outer whorl: the lateral outer staminode (Fig. 44). Eichler, thus, misidentifies an outer androecial member as an inner one. At this point in development two members of the outer androecial whorl remain uninitiated: the abaxial and adaxial outer staminodes, of which only the adaxial exists in the mature flower (both of these staminodes are lacking in Canna indica). The abaxial outer staminode is formed on the ring primordium between the labellum and inner staminode, while the adaxial outer staminode is formed between the inner staminode and the stamen (Fig. 44). Eichler makes two errors in observing the production of these organs. First, at the stage after all the outer staminodes are formed he mistakes the adaxial staminode primordium for the primordium which he previously described as being initiated on the left of the stamen (Fig. 45). Under this interpretation, the adaxial outer staminode does not exist as a member of the outer whorl. It is, rather, identified with a previously formed member of the inner whorl. Second, he identifies the primordia of the inner staminode and the outer abaxial staminode as two lobes of a single primordium that he says develops from the primordium formed on the left side of the stamen (Fig. 45). He claims that this double primordium gives rise to one of the petaloid floral parts which is, in the terminology used here, the inner staminode. By identifying two primordia as lobes of a single primordium he eliminates another member of the outer androecial whorl. The result of these misidentifications is that the outer androecial whorl is perceived as missing, while all of the petaloid floral members are identified as members of the inner whorl.

In his Bliitendiagramme, Eichler (1875) repeats the above interpretation and puts forward a second hypothesis on the structure of the flower in the Cannaceae. Under the latter interpretation, the stamen, labellum and one of the staminodes (the inner staminode) represent the inner whorl while the remaining one 
or two staminodes represent the outer whorl. This hypothesis receives support from Rao and Donde (1955) and Pai (1963), and is supported by the developmental work presented here.

Costerus $(1916,1917)$ also supports this view but with some major modifications. He suggests that the anther and petaloid appendage are members of different whorls, and cites the origin of the stamen from a double primordium (Payer, 1857; Eichler, 1873) to support this view. Under this interpretation the outer androecium consists of two petaloid staminodes one of which (the adaxial outer staminode) is produced from the same primordium which gives rise to the anther. The anther is thus seen as a member of the outer whorl. The third member of this whorl is generally missing as a mature structure, but is present in certain teratological forms. The inner whorl consists of the petaloid appendage, labellum and one petaloid staminode (the inner staminode). The connection of the anther with the petaloid appendage is seen as a completely arbitrary phenomenon which obscures its true relationship as a member of the outer whorl. An analogous interpretation is put forward (Costerus, 1917) for the androecium of the Marantaceae.

The evidence used to support the above hypothesis is drawn primarily from teratology. In the absence of the material examined by Costerus it is difficult to refute this theory. However, it receives no support from the developmental point of view despite Costerus' claims to the contrary. The mere fact that the stamen arises as a double primordium does not prove that it is composed of two members from different whorls. Its development is, rather, a reflection of the asymmetric developmental pattern found in the whole flower. This asymmetry of development is also evident in the formation of the labellum which begins separation from its associated petal in the region of the common primordium closest to the lateral sepal.

With the acceptance of the floral interpretations of the Marantaceae and Cannaceae discussed above the task of establishing the homologies of the floral parts pecomes an easy one. When two floral apices, one from each family (Fig. 33, 43), are compared, it is clear that there is an exact correspondence in number and relative position of primordia (Table 3 ). The common construction plan is: calyx, corolla, outer androecium, inner androecium, gynoecium.

Comparison of organogenesis_Floral development in the Marantaceae and Cannaceae is not well known. Most previous studies of these
TABLE 3. Floral homologies in the Cannaceae and Marantaceae

Floral member in Marantaceae

Abaxial sepalb

Lateral sepalb

Adaxial sepalb

Lateral petal

Adaxial petal

Abaxial petal

Abaxial staminode

Lateral staminode

Adaxial staminode

Stamen

Hooded staminode

Callose staminode

Floral member in Cannaceae

Conduplicate primordium Conduplicate primordium

Remaining two

gynoecial primordiac

Lateral sepal

Abaxial sepal

Adaxial sepal

Adaxial petal

Lateral petal

Abaxial petal

Lateral staminode

Abaxial staminode

Adaxial staminode

Stamen

Labellum

Inner staminode

Remaining two

gynoecial primordia

The difference in terminology used to identify homologous organs is due to the difference in floral orientation with respect to the florescence axis.

- The homologies of the sepals are based on their position in the flower not the sequence of initiation which is different for these two families.

There are no convenient terms to distinguish these primordia and no necessity to do so since they soon lose their distinctness through fusion to the conduplicate primordium.

families have concentrated on mature floral morphology (Eichler, 1875; Schumann, 1902; Kranzlin, 1912; Holttum, 1951; Pai, 1965), teratology (Costerus, 1916, 1917) and anatomy (Rao and Donde, 1955; Pai, 1963; Tilak and Pai, 1966, 1968, 1970). Payer's (1857) monumental work on the organogenesis of flowers contains a description of the development of Canna indica as does Thompson's (1933) study of flower and inflorescence structure in the Zingiberales. Eichler (1873) examined the development of several species of Canna including Canna indica. Thompson (1933) and Eichler (1883) are the only authors to discuss floral development in the Marantaceae and they present strikingly different pictures of organogenesis.

Eichler (1883) presents a description of development in Stromanthe sanguinea, Thalia dealbata and illustrates the development of Maranta bicolor. His descriptions are similar to those presented here.

Thompson (1933) describes the developmental patterns for many members of the Zingiberales including Canna indica, Clinogyne virgata (Marantaceae), and Thalia geniculata (Marantaceae). However, since his descriptions are at variance with all previous and subsequent work and because he illustrates these descriptions only with diagrams, his work will 
not be discussed in detail. In essence, he describes the initiation and fusion of 16 separate primordia which give rise to the various floral organs. For instance, the labellum of the Cannaceae is described as arising from a fusion of primordia numbers 8,13 and 16 , all members of different whorls. Nothing in the other literature or in the present investigation suggests that this is so. His descriptions of gynoecial development, however, are in agreement with those presented here.

All of the species examined in this study, except Canna indica show identical sequences of formation of floral parts. Once the difference in orientation of the flowers in the Marantaceae and Cannaceae is taken into account the only difference is in sepal formation. If we identify the sequence of formation as Sepal 1, Sepal 3, Sepal 2 in the Marantaceae the sequence in $C$. indica is Sepal 1, Sepal 2, Sepal 3. This latter sequence leads directly into the spiral created by the formation of the corolla and androecium in Canna. Thus, Canna shows one continuous spiral of organ formation while in the Marantaceae the spiral of the corolla and androecium is opposite that of the calyx.

This discrepancy in sepal formation between the Marantaceae and Cannaceae can be explained by hypothesizing that the shape of the floral apex during calyx formation (Fig. 9, 10) obscures the initial appearance of the lateral sepal in the Marantaceae. If this sepal were initiated before the adaxial sepal, then the initiation sequence in the two families would be identical. However, it has proven impossible to confirm this hypothesis through the observation of sectioned apices. Thus, it cannot be adopted without reservation.

The only variability in the patterns of organogenesis in the eight species investigated in this study is found in the formation of the inner androecium. The main differences deal with the amount and position of growth that occurs in the flanks of the common primordia after the initiation of the androecial and petal growth centers. Ischnosiphon elegans, Pleiostachya pruinosa, Marantochloa purpurea, and Canna indica are the only species which show a significant difference in the initiation of at least one androecial member. In I. elegans and $P$. pruinosa the stamen is initiated in the ventral flank of the common primordium below the initiation site of the petal. M. purpurea and Canna indica show a similar pattern of formation of the callose staminode and petal: the staminode is initiated in the flank of the common primordium, below the petal.

Perhaps the most surprising observation concerning organogenesis is that the formation of the inner androecium is not uniform within the genus Calathea. In many cases, the pattern of formation of a specific member of the inner androecium is more similar between a species of Calathea and a species of some other genus than it is among the species of Calathea. For example in the separation of the hooded staminode-petal primordium a truncate, two humped, primordium is formed. In Calathea vinosa, Ischnosiphon, Pleiostachya, Marantochloa, and Canna these outgrowths are of approximately the same size, while in Calathea leopardinia, Calathea lancifolia, and Monotagma the inner outgrowth is distinctly larger. This diversity of developmental patterns in Calathea reflects the variability of floral forms in this large genus (approximately 150 species). The similarities among the developmental patterns of the inner androecium, of species of Calathea and species of other genera are due to parallelisms.

Based on these results, it is possible to conclude that the amount of variability in organogenesis among closely related genera may be approximately the same as that found among distantly related species of a large genus. There is no way to predict how similar the patterns of organogenesis will be simply by knowing that the species which possess them belong to the same (or different) genera.

\section{LITERATURE CITED}

ANDERSSoN, L. 1976. The synflorescense of the Marantaceae. organization and descriptive terminology. Bot. Not. 129: 39-48.

1977. The genus Ischnosiphon (Marantaceae). opera Bot. 43: 1-113.

1981. The neotropical genera of Marantaceae. Circumscription and relationships. Nord. J. Bot. 1: 218-245

BERLYN, G. P., AND J. P. MIKSCHE. 1976. Botanical Microtechnique and Cytochemistry. Iowa State University Press, Ames.

CoSTERUS, J. C. 1916. A fresh investigation into the structure of the flower of Canna. Ann. Jard. Bot. Buitenzorg. 29, Deuxième Ser., Vol. 14: 165-184.

1917. Die Uebereninstimmung und der Unter-

schied in dem Bau der Blumen von Canna und derjenigen der Marantaceen. Ann. Jard. Bot. Buitenzorg. 30, Deuxième Ser., Vol. 15: 59-93.

EICHLER, A. W. 1873. Ueber den Blüthenbau von Canna. Bot. Zeitung 31: 177-189,193-198,208-218,225232,241-247.

1875. Blüthendiagramme construirt und erlaütert. Vol. 1. W. Engelmann, Leipzig.

1883. Beiträge zur Morphologie und Systematic der Marantaceen. Akad. Wiss. Berlin, Physik. Math. K1., Ab. I: 1-99.

Hourrum, R. E. 1951. The Marantaceae of Malaya. Gard. Bull Sing. 13: 254-296.

KAPLAN, D. R. 1967. Floral morphology, organogenesis and interpretation of the inferior ovary in Downingia bacigalupii. Amer. J. Bot. 54: 1274-1290. 
KENNEDY, H. 1977. Systematics and pollination of the "closed-flowered" species of Calathea (Marantaceae). Univ. Calif. Publ. Bot. 71: 1-90.

KRANZLIN, F. 1912. Cannaceae. In A. Engler [ed.], Das Pflanzenreich IV 47: 1-77.

PAI, R. M. 1963. The floral anatomy of Canna indica L. Bull. Bot. Soc. Coll. Sci., Nagpur 4(2): 45-53. . 1965. Morphology of the flower in the Cannaceae. J. Biol. Sci. 8: 4-8.

PAYER, J. B. 1857. Trait\& d'organogénie comparée de la fleur. Texte et Atlas. Librairie de Victor Masson, Paris.

PoSLUSZNY, U., M. G. SCoTT, AND R. SATTLER. 1980. Revisions in the technique of epi-illumination light microscopy for the study of floral and vegetative apices. Can. J. Bot. 58: 2491-2495.

RAo, V. S., AND N. DoNDE. 1955. The floral anatomy of Canna flaccida. J. Univ. Bombay 24(3): 1-10.

SATTLER, R. 1968. A technique for the study of floral development. Can. J. Bot. 46: 720-722.

SCHUMANN, K. 1902. Marantaceae. In A. Engler [ed.], Das Pflanzenreich IV 48: 1-176.
THoMPSoN, J. M. 1933. Studies in advancing sterility. Pt. VI. The theory of Scitaminean flowering. Publ. Hartley Bot. Lab. 11: 1-111.

TILAK, V. D., AND R. M. PAI. 1966. Studies in the floral morphology of the Marantaceae I. Vascular anatomy of the flower of Schumannianthus virgatus Rolfe, with special reference to the labellum. Can. J. Bot. 44: 1365-1370.

, AND. 1968. Studies in the floral morphology of the Marantaceae. II. Vascular anatomy of the flower in two species of the genus Phrynium Willd. Proc. Indian Acad. Sci. Sec. B. 68(5): 240-249.

, AND. 1970. Studies in the floral morphology of the Marantaceae III. Vascular anatomy of the flower in some species of the genus Calathea. Marathwada Univ. J. Sci. 9 Sci. 2: 31-41.

WEBERLING, F. 1965. Typology of inflorescences. Bot. J. Linn. Soc. London 59: 215-221. 